\title{
A NEW SLAVE-MAKING ANT FROM JAPAN.
}

$$
\text { By M. Yano, }
$$

Imperial Forestry Experiment Station, Tokyo, Japan.

One of the most interesting Japanese ants in my collections is a slave-making species, belonging to Polyergus, and apparently distinct from the known European and North American forms of the genus.

Polyergus rufescens Latreille subsp. samurai subsp. nov.

Worker. Length 5-6 mm.

Head nearly pentagonal, excluding mandibles; with somewhat parallel sides, prominent occipital portion and nearly straight

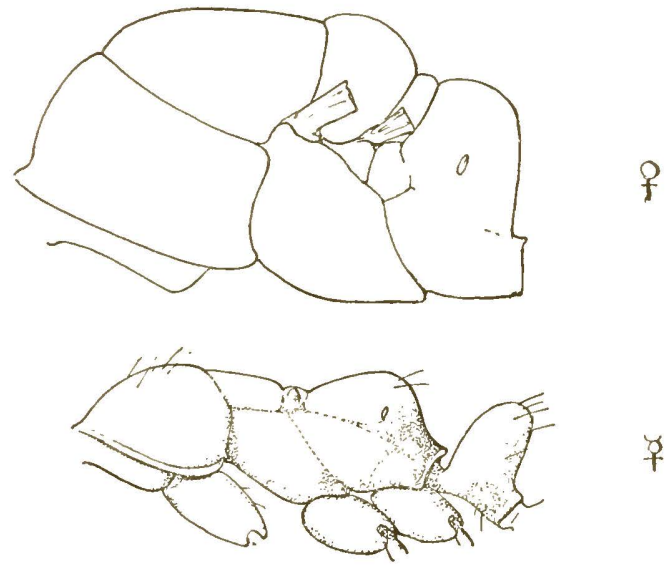

Fig. 1. Polyergus rufescens Latr., subsp. samurai subsp. nov. Profile of thorax in female and worker.

posterior border; the mandibles narrow and long, curved inward, pointed, with a ninutely dentate masticatory margin, clypeus triangular, broad, and flat, its anterior margin nearly straight; frontal area small, distinctly broader than long, its posterior suture rounded, anterior suture nearly straight; median line long and distinct; antennal carinæ not distinct; antennæ rather short, the scapes just reaching to the posterior border of the head, somewhat swollen apically, the flagellum long, filiform; ocelli very distinct; 
eyes prominent. Thorax a little narrower than the head; pronotum rounded above and in front; mesonotum longer than broad, flat above; pro-mesonotal suture distinct, with a lateral distinct suture between the mesonotum and mesopleuræ; meso-metanotal depression very wide; epinotum a little narrower than the pronotum, much produced, rather sharply rectangular between the basal portion and declivity, the basal portion as long as the declivity, the former slightly convex, the latter feebly concave. Node of petiole very thick, distinctly narrower than the epinotum, the upper surface rounded and broad, anterior slope very convex, posterior slope flat and convex below, gaster short, from above subspherical.

Body finely punctured and opaque above; under surface of the body, legs, mandibles, and tip of gaster somewhat shining.

Hairs brownish, sparse, bristly and erect, scattered on the clypeus, dorsum of pronotum and metanotum, upper edge of the node of petiole and gaster; mandibles with fine and short hairs; grayish pubescence very fine, dense on the upper half of the body, including antennæ and legs.

Brownish black to deep reddish brown; antemnæ and legs somewhat paler.

Female (deälated). Length $7.5 \mathrm{~mm}$.

Resembling the worker and female of the typical form. Mesonotum flat above; epinotum more gibbous, the basal portion shorter than the declivity. Body black; mouth parts, antennæe and legs chestnut brown, and the flagellum and tarsus paler. Bristly hairs scanty; golden pubescence rery dense on upper surface of thorax and abdomen, obscure on the head and legs.

Habitat. Prov. Hyûga (M. Yano); Prov. Buzen (M. Yano.); Tokyo (M. Oguma and M. Yano).

This subspecies differs from the typical rufescens in its darker color, more opaque surface, shorter pubescence, and in the shape of the epinotum which is more angular than in the European and North American forms of rufescens.

This ant is a rather common species near Tokyo and in Kiûiû, and probably throughout middle Japan. It inhabits nests in the earth in the most exposed situations and eren in dry fields. The slaves of this ant are Formica fusca fusca var. japonica Motschulsky (=F. fusca nipponensis Forel), a common species in my 
country, and curiously seem to resemble it in general appearance. Their expeditions are made during the afternoon from the end of June to August, occasionally three times in the same day.

I wish to tender my sincere thanks to Prof. W. M. Wheeler for his raluable suggestions.

March 15, 1911.

\section{ON MELANETERICS INFERTALIS FALL.}

\section{By Milliam Morton Wheeler, Harvard University.}

The singular Histerid beetle Melanetarius infernalis was first described by Fall in this journal in $1907^{1}$ from a single individual taken at Pasadena, California, Dec. 1st, 1902, "from nest of unknown ant." While I was on a collecting trip during the past winter in Arizona and California Mr. Fall showed me the type specimen, which he had found in a collection obtained from a local entomologist who had died without leaving any information concerning the precise locality in which the beetle had been captured. By a strange coincidence, while I was collecting Dec. 1st, 1910, on the anniversary of the taking of this type specimen, I not only rediscorered the beetle but was able to ascertain the host-ant with which, in all probability, it normally lives. In a small canyon that enters the west side of the Gran Arroyo Seco near Pasadena, I found several nests of the typical yellow form of Pheidole hyatti Emery. All of these were under rather large stones, and from one of the nests, which was somewhat isolated and in the middle of the floor of the canyon, I took seven specimens of the Melanetarius. They were all quietly clinging to the under surface of the stone in the midst of the ants and made no effort to escape when the nest was disturbed. A few hundred yards from this spot and at the very opening of the side canyon into the Arroyo I found another colony of the same ant containing a single specimen of the beetle.

All of the specimens agree very closely with one another and

\footnotetext{
${ }^{1}$ Two New Myrmecophilous Histeridæ. Psyche XIV, Aug. 1907, pp. 65-70.
} 

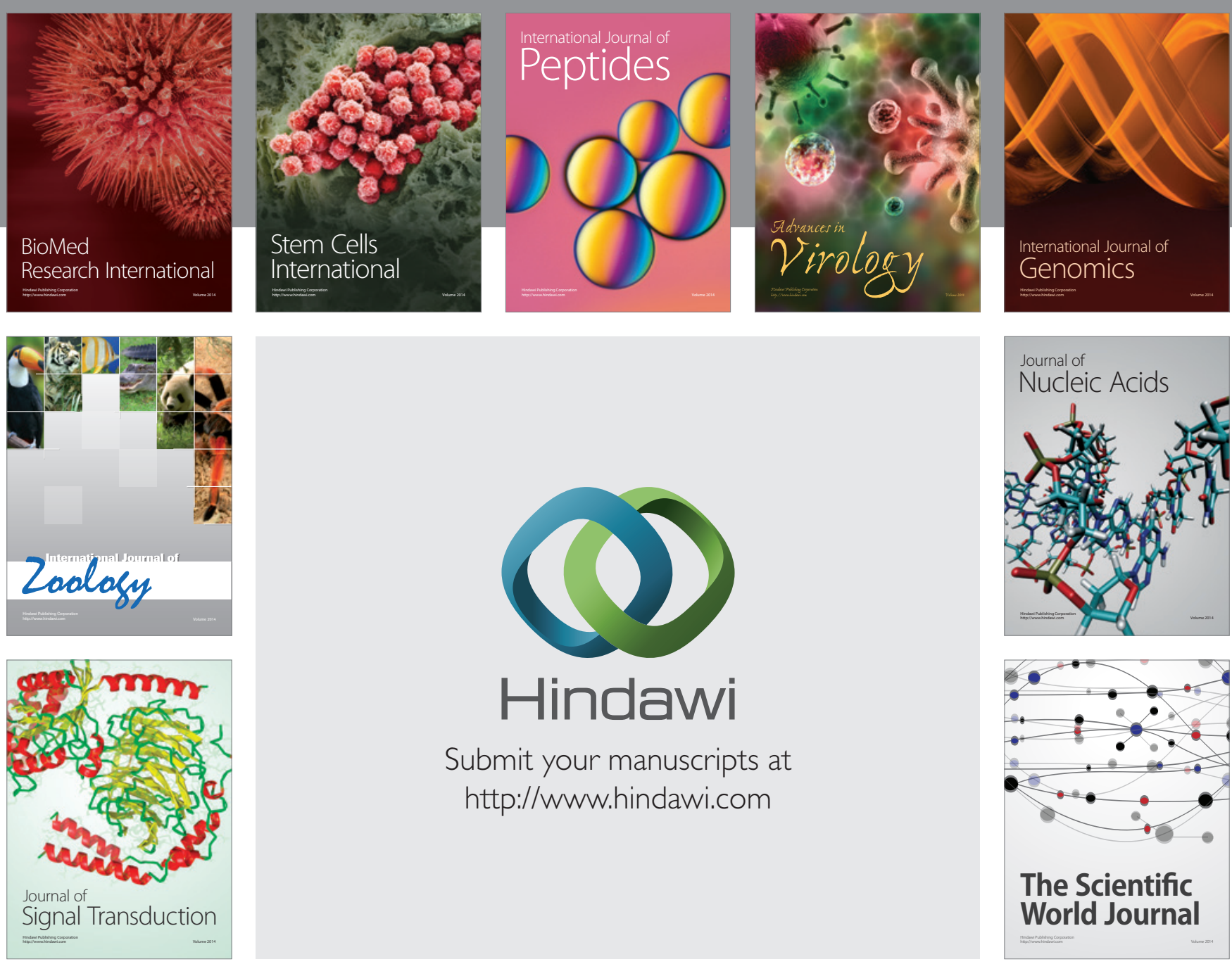

Submit your manuscripts at

http://www.hindawi.com
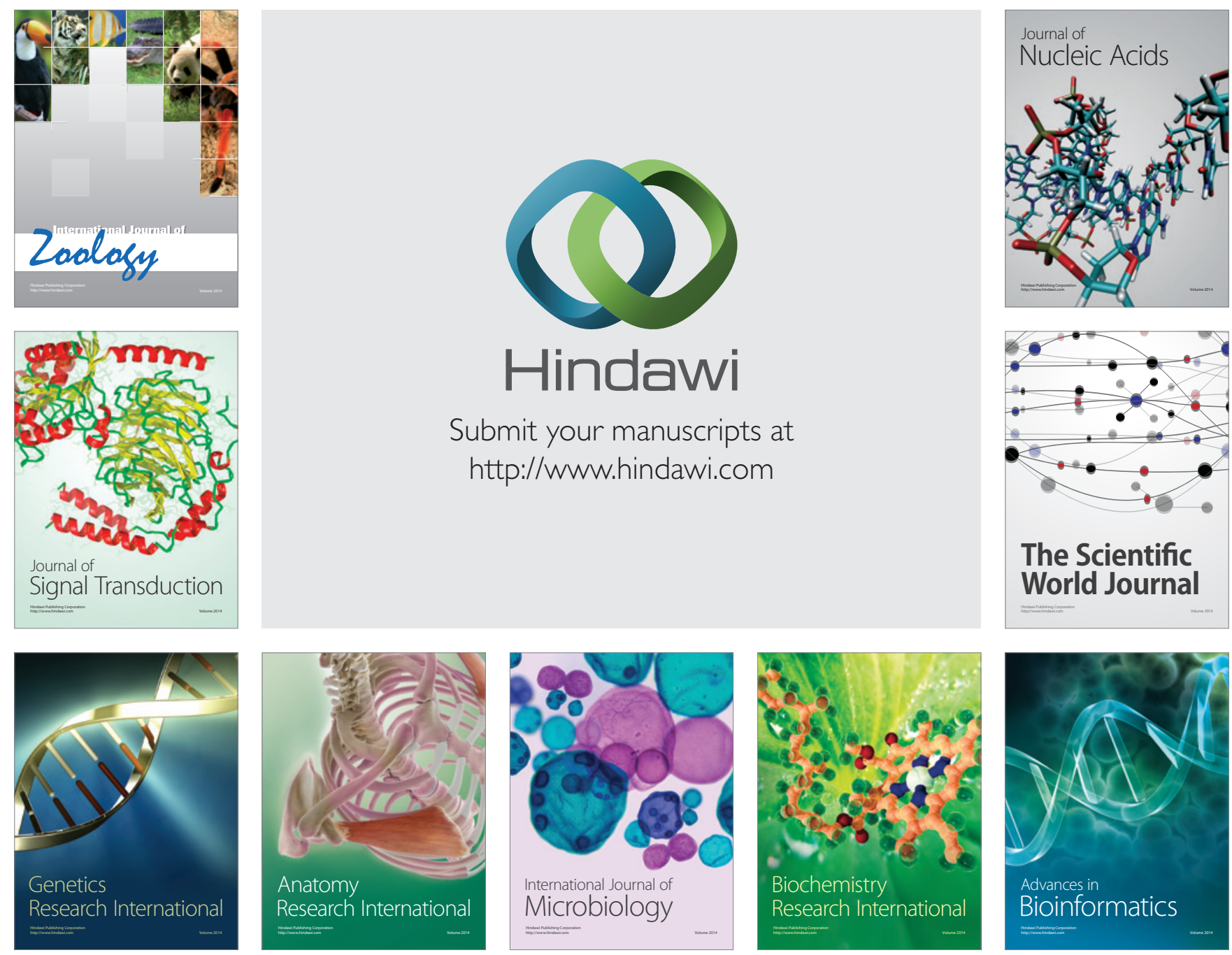

The Scientific World Journal
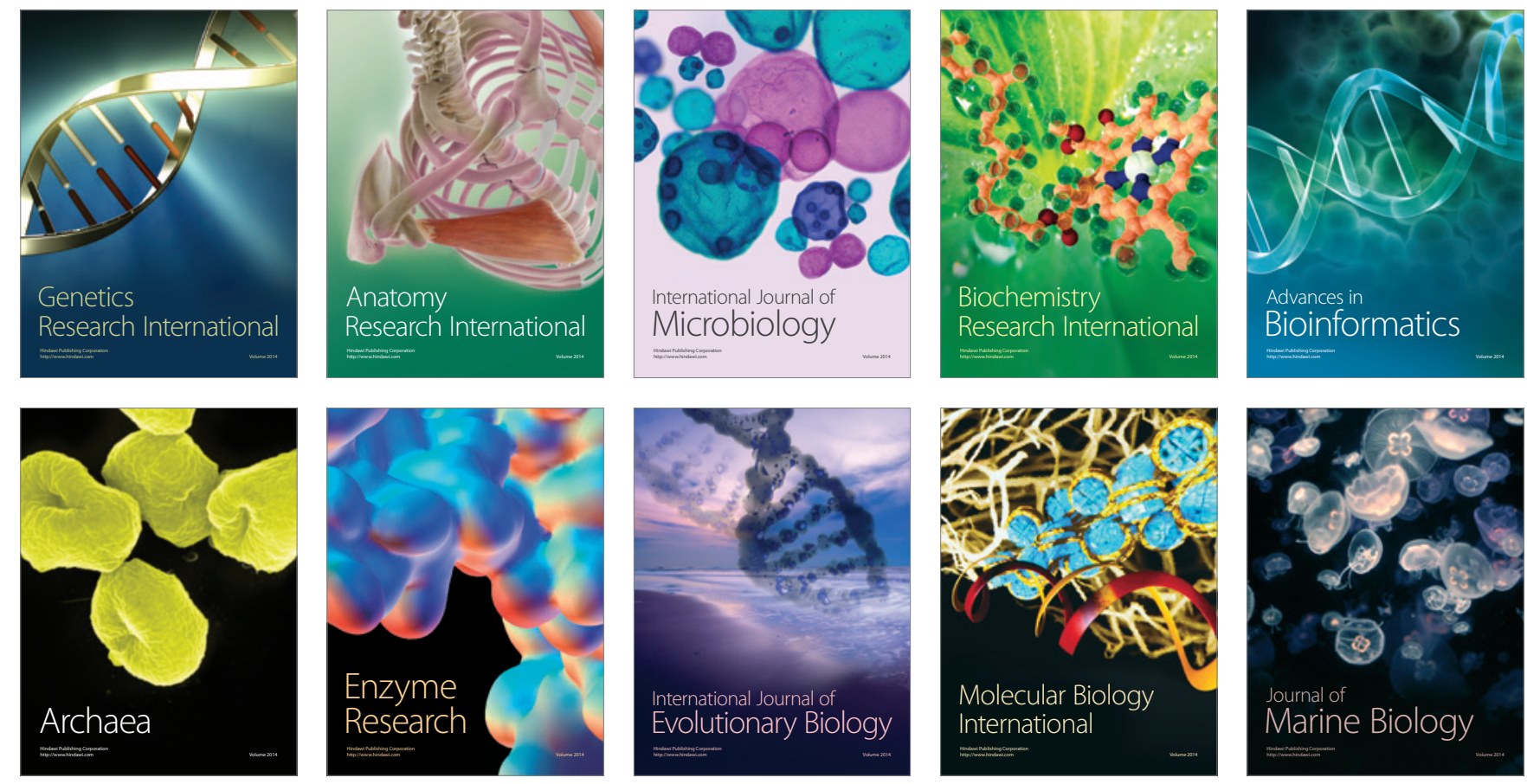